\title{
Anti-oxidation properties of leaves, skin, pulp, and seeds extracts from green papaya and their anti- cancer activities in breast cancer cells
}

\author{
Shrefa A. Hadadi',3, Haiwen Li', Reza Rafie ${ }^{2}$, Paul Kaseloo ${ }^{3}$, Sarah M. Witiak ${ }^{3}$, Rafat A. Siddiqui' \\ ${ }^{1}$ Food Chemistry and Nutrition Science Laboratory, Virginia State University, Petersburg, VA 23806, USA. \\ ${ }^{2}$ Cooperative Extension, Agricultural Research Station, College of Agriculture, Virginia State University, Petersburg, VA 23806 , \\ USA. \\ ${ }^{3}$ Department of Biology, College of Natural and Health Sciences, Virginia State University, Petersburg, VA 23806, USA.
}

Correspondence to: Dr. Rafat A. Siddiqui, Food Chemistry and Nutrition Science Laboratory, Virginia State University, Petersburg, VA 23806, USA.E-mail: rsiddiqui@vsu.edu

How to cite this article: Hadadi SA, Li H, Rafie R, Kaseloo P, Witiak SM, Siddiqui RA. Anti-oxidation properties of leaves, skin, pulp, and seeds extracts from green papaya and their anti-cancer activities in breast cancer cells. $J$ Cancer Metastasis Treat 2018;4:25. http://dx.doi.org/10.20517/2394-4722.2018.22

Received: 9 Mar 2018 First Decision: 10 Apr 2018 Revised: 29 Apr 2018 Accepted: 15 May 2018 Published: 30 May 2018

Science Editors: Umberto Galderisi Copy Editor: Jun-Yao Li Production Editor: Huan-Liang Wu

\begin{abstract}
Aim: Breast cancer is typically detected either during a screening examination or after a woman notices a lump. Breast cancers have different phenotypes depending on the presence/absence of an estrogen receptor (ER) and/or an epidermal growth factor (Her-2) receptor. The objective of the present investigation was to investigate growth inhibitory activity of methanol-, ethanol-, and water-extracts from papaya fruit and leaves on MDA-MB-231 (ER'/Her-2), MCF-7 (ER $\left.{ }^{+} / \mathrm{Her}-2^{-}\right)$, SK-BR- 3 (ER/Her-2 $\left.{ }^{+}\right)$and MDA-MB-361, AU565 (ER $/$Her-2 ${ }^{+}$) breast cancer cells.
\end{abstract}

Methods: The anti-oxidation potential of papaya extracts was determined by assessing their total polyphenol content, total flavonoid content and by assaying their anti-oxidation capacity. The effects on breast cancer cells proliferation were determined using a WST-1 assay.

Results: The seeds and leaves contained higher anti-oxidation potential than that of the skin and pulp fractions. Our data indicate that methanol- and ethanol-extracts of papaya leaves, skin, pulp, and seeds have no effect on any of the breast cancer cell lines, whereas water-extract of leaves and seeds caused low to modest cytotoxic effects only on ER-negative breast cancer cell lines.

Conclusion: Our data suggest that bioactive compound in papaya leaves can be potentially used to develop anti-cancer agents for ER-negative breast cancer.

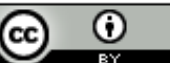

(C) The Author(s) 2018. Open Access This article is licensed under a Creative Commons Attribution 4.0 International License (https://creativecommons.org/licenses/by/4.0/), which permits unrestricted use, sharing, adaptation, distribution and reproduction in any medium or format, for any purpose, even commercially, as long as you give appropriate credit to the original author(s) and the source, provide a link to the Creative Commons license, and indicate if changes were made. 
Keywords: Breast cancer, papaya leaves, antioxidants, polyphenols

\section{INTRODUCTION}

Cancer is the second most common cause of death in the US ${ }^{[1]}$ About 1,685,210 people were estimated to have been diagnosed with cancer, and an estimated 595,690 were expected to die from it in $2016^{[2]}$. According to a published report, an estimated 14 million cases of cancer reported worldwide and nearly half (about $13 \%$ of the total worldwide deaths) died from cancer ${ }^{[3]}$. According to National Cancer Institute (2016), the most common cancer in the world is breast cancer in females and prostate cancer in males, followed by lung cancer. However, lung cancer causes more deaths than breast or prostate cancer ${ }^{[4]}$. Breast cancer is characterized in different molecular phenotypes based on three cellular receptors: estrogen receptor (ER), progesterone receptor (PR), and the epidermal growth factor receptor family member $(\mathrm{Her}-2 / \mathrm{Neu})$. According to this classification a breast cancer can be $\mathrm{ER}^{+} / \mathrm{PR}^{+} / \mathrm{Her}-2^{+}, \mathrm{ER}^{+} / \mathrm{PR}^{+} / \mathrm{Her}-2, \mathrm{ER} / \mathrm{PR} / \mathrm{Her}-2^{+}$, or

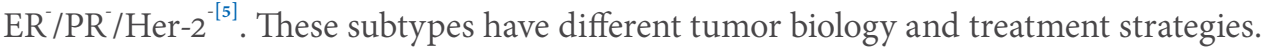

The early and advanced hormone positive breast cancers can be effectively treated with endocrine therapy which blocks the estrogen production and/or inhibits the effect of estrogen at the receptor level ${ }^{[6]}$. Tamoxifen is a selective modulator of ER which is used as a gold-standard adjuvant treatment since 1995 for pre-and postmenopausal patients at low-risk of recurrence ${ }^{[7]}$. More recently, aromatase inhibitors (AIs) including drugs letrozole, anastrozole, and exemestane are developed which inhibit enzyme aromatase and reduce estrogens formation from androgen ${ }^{[8,9]}$. Other recent developments in breast cancer therapy include the development of strategies to inhibit Her-2 activity, especially in Her-2 positive breast cancer by monoclonal antibodies and by antibody fragments ${ }^{[10,11]}$. The recently developed humanized monoclonal antibody, trastuzumab (Tra), specifically targets the extracellular domain of Her-2, which is approved by the Food and Drug Administration (FDA) for the treatment of $\mathrm{Her}_{-2}{ }^{+}$breast cancer ${ }^{[12,13]}$. Another strategy to treat breast cancer is to develop inhibitors for angiogenesis. Angiogenesis is a process where new blood vessels are formed from existing vessel ${ }^{[14]}$. The strategies to reduce angiogenesis are (1) the development of antibodies or small molecules against vascular endothelial growth factor, basic fibroblast growth factor or platelet-derived growth factor to inhibit action of these proangiogenic factors and (2) the use of endogenous angiogenesis inhibitors including thrombopondin-1, endostatin, angiostatin, arresten, canstatin and tumstatin ${ }^{[15,16]}$. Although successful, these treatments for breast cancer have considerable side effects and often patients develop resistance to these drugs. There is a growing interest to use natural products for as an alternative or adjunct strategy to treat and prevent breast cancer.

Several epidemiological studies have shown that consumption of fruits, and vegetables (especially soy and cruciferous vegetables) are linked to reduced risk of breast cancer ${ }^{[17,18]}$, and some dietary natural products consumption might increase the survival rate of breast cancer by reducing the recurrence ${ }^{[19,20]}$. Several experimental studies have also shown that dietary natural products and their bioactive compounds can be very effective in reducing breast cancer growth because they are able to downregulate ER- $\alpha$ expression and activity; inhibit tumor proliferation, metastasis and angiogenesis of breast tumor cells; induce apoptosis and cell cycle arrest; and sensitize breast tumor cells to radiotherapy and chemotherapy ${ }^{[21,22]}$. It has been shown that the breast carcinogenesis occurs due to oxidative damage of mitochondrial DNA by reactive oxygen species $(\mathrm{ROS})^{[23,24]}$. In a review article, studies were discussed indicating that the effects on cancer cells by fruits and vegetables, which are rich in flavonoids and other phenolic compounds, have been associated with their abilities to reduce or inhibit free radical-mediated damage to cellular macromolecules, such as proteins, lipids, and $\mathrm{DNA}^{[25]}$. These observations suggest that there may be an inverse association between antioxidation properties and cancer cell growth. The consumption of natural-dietary substances is, therefore, suggested as a useable approach for the prevention and/or treatment of breast cancer ${ }^{[26]}$. 
The papaya (Carica papaya Linn) tree that belongs to a family Caricaceae, is originated in southern Mexico and Costa Rica. Now it is grown all over the world including Australia, Hawaii, Philippines, Sri Lanka, South Africa, India, and in all tropical and subtropical regions. Some counties produce papaya on a commercial scale for export; however, in most of the tropical regions it can be grown in home gardens ${ }^{[27]}$. Traditionally, all parts of papaya including roots, seeds, flowers, fruit, latex, barks, and leaves have been used to treat a number of diseases in various regions in the world. Papaya has also been studied for its anticancer activities for colorectal $^{[28]}$, prostate ${ }^{[29,30]}$, cervical ${ }^{[31]}$ and breast cancers ${ }^{[32]}$. The fruit, seeds, or leaves extracts of papaya have been shown to possess cytotoxic and anti-proliferative activities for a number of cancer cells lines including breast (MCF-7), liver (HepG2) and cervical carcinoma (Hela), lung adenocarcinoma (PC14), oral squamous cell carcinoma (SCC25), pancreatic epithelioid carcinoma (Panc-1), mesothelioma (H2452), and cancer of haematopoietic cell lines, including T cell lymphoma (Jurkat), plasma cell leukemia (ARH77), Burkitt's lymphoma (Raji), and anaplastic large cell lymphoma (Karpas-299) and human promyelocytic leukaemia $(\mathrm{HL}-60)^{[33-35]}$. The lipophilic extracts of papaya pulp inhibited cell proliferation of $\mathrm{ER}^{+}$breast cancer MCF-7 cells but did not inhibit ER breast cancer MDA-MB-231 cells ${ }^{[36]}$. During present investigation, the effect of papaya extracts from leaves, skin, pulp and seeds were assessed on estrogen and Her-2dependent and -independent breast cancer using representative cells lines.

\section{METHODS}

\section{Materials}

MDA-MB-231 (ER/PR/Her-2; triple negative), MCF-7 (ER $\left.{ }^{+} / \mathrm{PR}^{+} / \mathrm{Her}-2{ }^{-}\right)$, SK-Br-3 (ER/PR/Her-2 $\left.{ }^{+}\right)$, AU565 $\left(\mathrm{ER}^{-} / \mathrm{PR}^{-} / \mathrm{Her}-2^{+}\right)$, and MDA-MB-361 $\left(\mathrm{ER}^{+} / \mathrm{PR}^{+} / \mathrm{Her}-2^{+}\right)$breast cancer cell were purchased from ATCC (Manassas, VA 20110). F-12K (21127-022) media was purchased from Gibco (Grand Island, NY14072). Fetal bovine serum was purchased from RAMBIO (Missoula, Montana). Antibiotics: penicillin and streptomycin, and phosphate buffered saline was purchased from Fisher (Fair lawn, New Jersey). Folin-Ciocalteu, aluminum chloride, Diphenyl-1-picrylhydrazyl (DPPH), quercetin, gallic acid, and Trolox were purchased from Sigma Chemical Co (St Louis, MO). Green papaya was obtained from Randolph Farm at Virginia State University. WST-1 (MK400) was purchased from Talkara (Kusatsu, Shiga, Japan).

\section{Isolation of papaya leaves, skin, pulp, and seeds}

Unripe green papaya (2-3 kg) was obtained from Randolph Farm at Virginia State University, Petersburg VA. The papaya was washed with distilled water, then blotted dry with paper towel. The skin was peeled off using a kitchen peeler. The unskinned papaya was cut into half to remove seeds and then the pulp was cut into small pieces. The leaves and seeds were washed with distilled water. All fractions (leaves, skin, pulp and seeds) were spread on a plastic trays and left for drying in a chemical hood until a constant weight was obtained. The dried leaves, skin, pulp and seeds were ground to a fine powder using a mortar and pestle. The dried powder was flash frozen with nitrogen and stored at $-80{ }^{\circ} \mathrm{C}$ until used.

\section{Preparation of leaves, skin, pulp and seeds extract}

A known quantity ( $5 \mathrm{~g}$ ) of dried papaya powder was mixed with $200 \mathrm{~mL}$ of $80 \%$ methanol, $60 \%$ ethanol, or $100 \%$ distilled water. The mixtures were placed on a shaker at room temperature overnight. The next day, the mixture was centrifuged at $1500 \mathrm{~g}$ for $20 \mathrm{~min}$ using a Thermo Scientific centrifuge (Waltham, MA). The supernatant was collected and the residues were washed 2 times by suspending them again in the respective solutions, mixing, and placing on shaker overnight. The collected supernatant was pooled together and the residues were discarded. The ethanol and methanol extracts were dried in a nitrogen evaporator (Organomation Associates, Inc, Berlin, MA) whereas the water extract was freeze dried. The dried extract was stored in a $-20{ }^{\circ} \mathrm{C}$ freezer.

\section{Determination of total phenolic content}

The total phenolic content (TPC) of papaya extract was determined by using Folin-Ciocalteu method as 


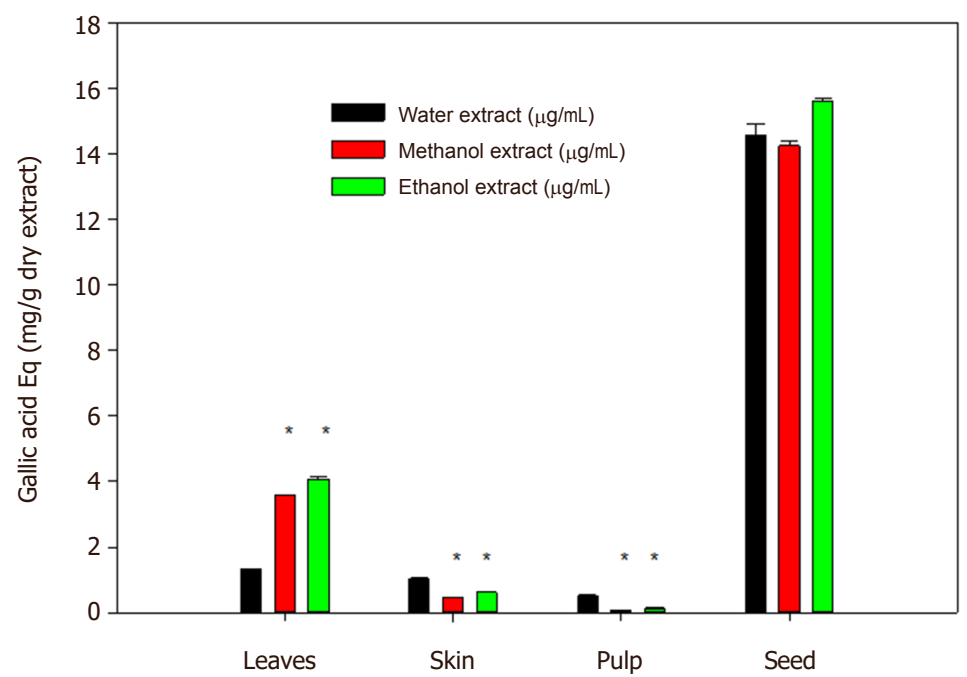

Figure 1. Total polyphenols analysis from various papaya fractions. The total phenolic content (TPC) of papaya extract was determined by using Folin-Ciocalteu method. Results are mean \pm SD for at least 3 experiments as gallic acid equivalents. The TPC in methanol and ethanol extracts were compared to that in the water extracts. The significant differences, as marked "*", are reported at $P<0.05$

described $^{[37]}$. The TPC content of the papaya extract was calculated as gallic acid equivalents.

\section{Determination of total flavonoid content}

An aluminum-chloride based assay was used to determine the total flavonoid content (TFC) of the extracts $^{[38]}$. Quercetin was used as standard and flavonoid content was determined as quercetin equivalent.

\section{Anti-oxidation capacity assay}

The anti-oxidation activity in papaya extracts was assayed by using 2, 2-Diphenyl-1-picrylhydrazyl (DPPH) method $^{[39]}$. The data is reported as \% inhibition of DPPH oxidation.

\section{Cell culturing and anti-proliferation assay}

MDA-MB-231, MCF7, MDA-MB-361, and AU565 cells were maintained in Dulbecco's modified eagle medium (DMEM; Invitrogen; Carlsbad, CA) supplemented with penicillin (100 units $/ \mathrm{mL}$ ), streptomycin $(100 \mu \mathrm{g} / \mathrm{mL})$ and 10\% FBS. SK-Br-3 cells were maintained in McCoy's 5A medium (ATCC) supplemented with penicillin (100 units $/ \mathrm{mL})$, streptomycin $(100 \mu \mathrm{g} / \mathrm{mL}$ ) and $10 \%$ FBS. All cell cultures were incubated in a humidified incubator at $37{ }^{\circ} \mathrm{C}$ and $5 \% \mathrm{CO}_{2}$. Media was changed every 3 days and cells were subculture when they became confluent. Effect of papaya leaves, skin, pulp and seeds extract on cell proliferation was determined using a WST-1 assay as per manufacturer instructions. The results are expressed as \% change from control.

\section{RESULTS}

\section{Characterization of papaya extract for anti-oxidation activity}

The anti-oxidation potential of papaya extracts was determined by assessing their total polyphenol content, total flavonoid content and by assaying their anti-oxidation capacity. The data showing the TPC is presented in Figure 1. The highest amount of TPC was found in the seeds extract that ranged from $14-16 \mathrm{mg} / \mathrm{g}$ dry weight of the extracts. There was no significant difference in TPC content between water, ethanol and methanol extracts. The leaves were second highest in TPC content but had a considerably lower amount of TPC than that of seeds. The leaves contained TPC in 1-4 mg/g of dry weights. Water extract contained a lower amount of TPC ( 1 mg/g dry weight) than that of ethanol or methanol extract. The amounts of TPC between ethanol and methanol extracts from papaya leaves were not significantly different. The skin 


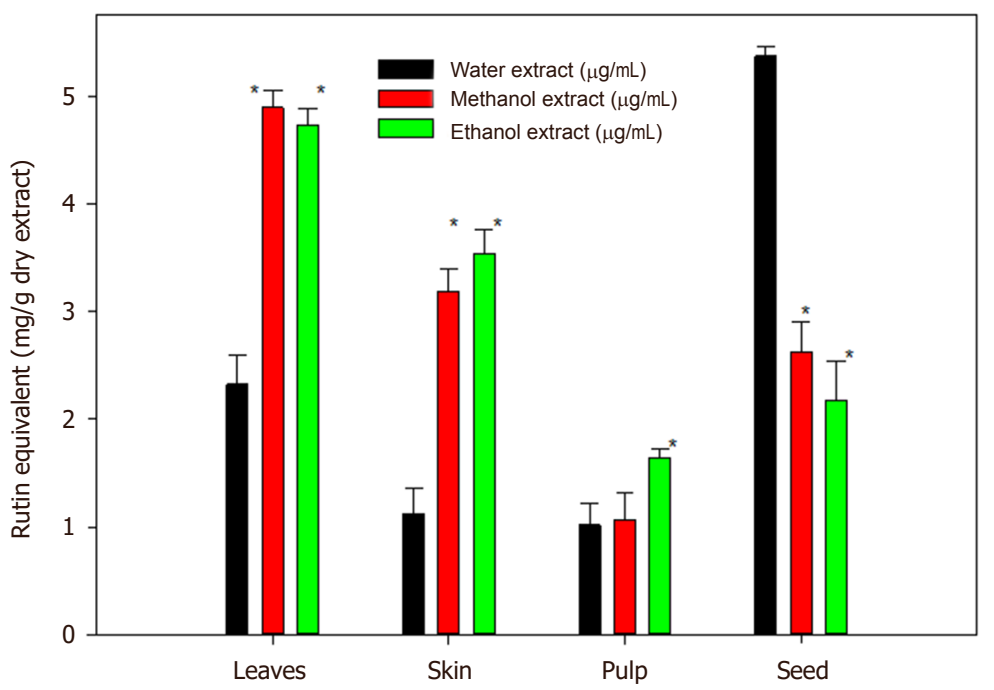

Figure 2. Total flavonoid content in various papaya fractions. Aluminum chloride complex forming assay was used to determine the total flavonoid content (TFC) of the extracts. Results are mean \pm SD for at least 3 experiments as quercetin equivalent. The TFC in methanol and ethanol extracts were compared to that in the water extracts. The significant differences, as marked "*", are reported at $P<0.05$

extracts contained TPC under $1 \mathrm{mg} / \mathrm{g}$ dry weight whereas the pulp extracts have very small amounts of TPC (0.05-0.5 mg/g dry weight).

The data for the TFC content in various papaya fraction are presented in Figure 2. The seeds and leaves extracts contained the highest amounts of TFC ranging $2-5.5 \mathrm{mg} / \mathrm{g}$ dry weight. The ethanol or methanol extract of leaves contained more TFC ( $\sim 5 \mathrm{mg} / \mathrm{g}$ dry weight) than that of water extract ( $\sim 2 \mathrm{mg} / \mathrm{g}$ dry weight). However, water extracts of seeds contained more TFC $(\sim 5.5 \mathrm{mg} / \mathrm{g}$ dry weight) than that of ethanol or methanol extracts $(\sim 2-2.5 \mathrm{mg} / \mathrm{g}$ dry weight). The amount of TFC in pulp and skin were less than that of seeds and leaves. In skin, higher amounts of TFC were present in the ethanol and methanol extracts $(\sim 3.2-3.5 \mathrm{mg} / \mathrm{g}$ dry weight) than that of water extract (> $1 \mathrm{mg} / \mathrm{g}$ dry weight). The pulp contained a lower amount of TFC than that of other fractions. The total amount of TFC in pulp ranged $1-1.5 \mathrm{mg} / \mathrm{g}$ dry weight.

The anti-oxidation capacity of papaya fractions was measured by assaying the inhibition of DPPH oxidation and is shown in Figure 3. The seeds and leaves contained the most anti-oxidation capacity than that of the skin and pulp fractions. The ethanol and methanol fractions of seeds and leaves contained more antioxidation activity than that of water extracts. The ethanol and methanol fractions of seeds and leaves inhibited DPPH oxidation by $75 \%-85 \%$ whereas the water extracts of these fractions inhibited DPPH oxidation by $50 \%-70 \%$. The skin and pulp inhibited DPPH oxidation from $25 \%$ to $35 \%$. There was no significant difference between water, ethanol or methanol extracts of skin or pulp.

\section{Effect of papaya leaves, skin, pulp and seeds extract on MDA-MB-231 breast cancer cells}

This experiment was carried out to investigate effect of papaya extracts on ER/Her-2 breast cancer cell line using MDA-MB-231. The effect of water extract from leaves, skin, pulp and seeds is shown in Figure 4A. When the cells were treated with water extract of papaya leaves, the cells viability is reduced in a dosedependent manner reaching a significant reduction of $20 \%(P<0.05)$ at $150 \mu \mathrm{g} / \mathrm{mL}$. On further increasing the concentration of extract, the cell viability was further reduced to $30 \%(P<0.05)$. Water extract of skin has no significant effect except at the highest concentration $(250 \mu \mathrm{g} / \mathrm{mL})$ where cell viability is reduced by a marginal $10 \%(P<0.05)$. The pulp extract has no significant effect at any concentration. The water extract of seeds exhibited an effect similar to the water extract of the leaves causing a significant reduction in cell viability by $20 \%(P<0.05)$. 


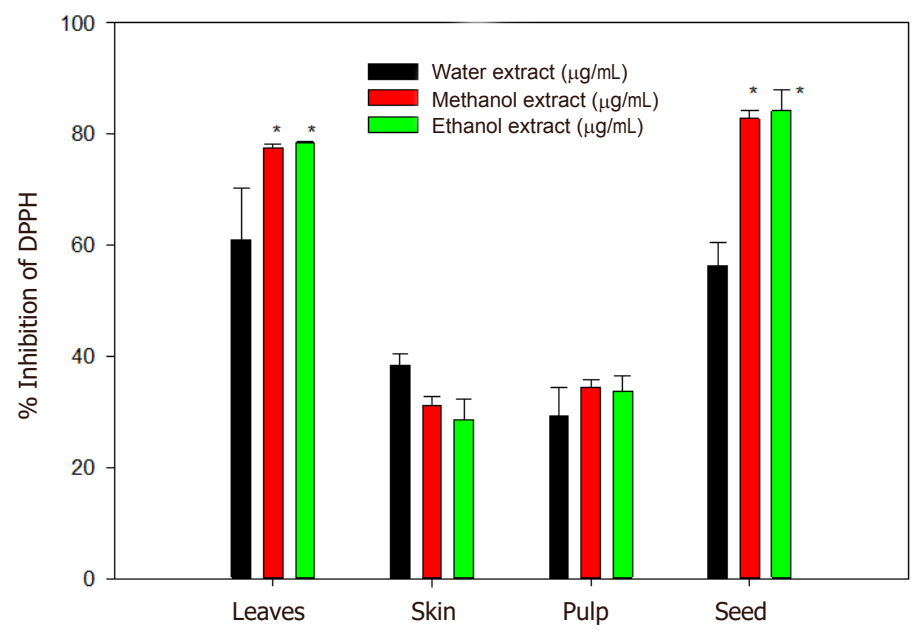

Figure 3. Anti-oxidation capacity of papaya fractions. The anti-oxidation activity in papaya extracts was determined by using 2 , 2-Diphenyl-1-picrylhydrazyl (DPPH) method. The data is reported as \% inhibition of DPPH oxidation. Results are mean \pm SD for at least 3 experiments. The results of methanol and ethanol extracts were compared to that of the water extracts. The significant differences, as marked "*", are reported at $P<0.05$

The effect of methanol extract from leaves, skin, pulp and seeds is shown in Figure $4 \mathrm{~B}$. The data indicate that none of the papaya fractions has any significant effect on cell viability of MDA-MB-231 breast cancer cells.

The effect of ethanol extract from leaves, skin, pulp and seeds is shown in Figure 4C. The extract from leaves, skin, and pulp has no significant effect; however, seed extract reduced cell viability starting at $75 \mu \mathrm{g} / \mathrm{mL}$. The cell viability was reduced significantly by $20 \%(P<0.05)$ at the highest concentration of $250 \mu \mathrm{g} / \mathrm{mL}$.

\section{Effect of papaya leaves and seeds extract on MCF-7 breast cancer cells}

As we found from our previous experiment, neither the water, methanol nor ethanol extracts from pulp and skin had any effect on breast cancer cells; however, leaves and seeds showed effects on cell proliferation. We, therefore, carried out subsequent experiments on the extracts from leaves and seeds only. The effect of water extract from leaves and seeds is shown in Figure 5A. The extract from seeds, has no significant effect; however, leaves extract reduced cell viability significantly by $30 \%(P<0.05)$ at the highest concentration of $250 \mu \mathrm{g} / \mathrm{mL}$.

The effect of methanol extract from leaves and seeds is shown in Figure 5B. The data indicate that none of the papaya fractions has any significant effect on cell viability of MCF-7 breast cancer cells.

The effect of ethanol extract from leaves and seeds is shown in Figure 5C. Similarly, our data indicate that none of the papaya fractions has any significant effect on cell viability of MCF-7 breast cancer cells.

\section{Effect of papaya leaves and seeds extract on SK-Br-3 breast cancer cells}

We performed further experiments to test the effect of papaya extracts in ER/Her-2 ${ }^{+}$breast cancer using SKBr-3 cells. As explained above, we only tested extracts from leaves and seeds on these cells.

The effect of water extract from leaves and seeds is shown in Figure 6A. The extract from seeds has no significant effect except at the highest concentration $(250 \mu \mathrm{g} / \mathrm{mL})$ where cell viability is reduced by $25 \%(P<$ 0.05). However, leaf extract reduced cell viability in a dose-dependent manner starting at $10 \mu \mathrm{g} / \mathrm{mL}$. The cell variability was reduced significantly by $50 \%(P<0.05)$ at the highest concentration of $250 \mu \mathrm{g} / \mathrm{mL}$. 
A

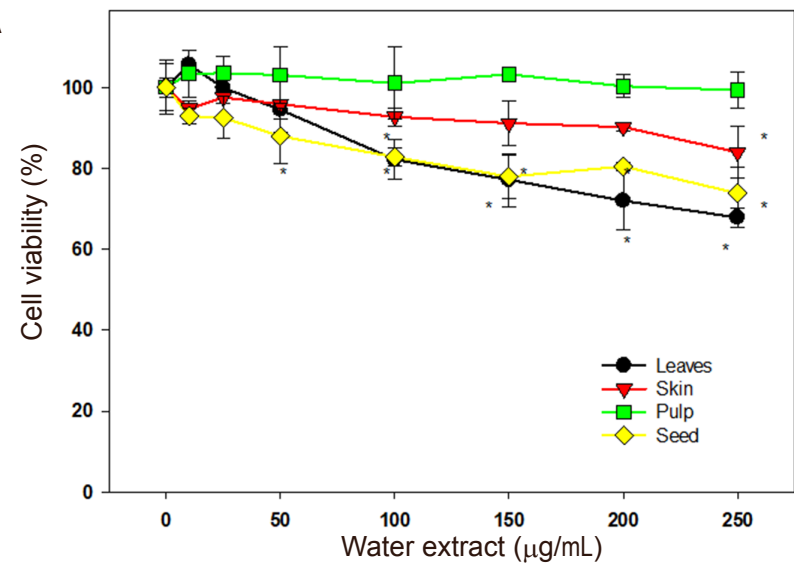

B
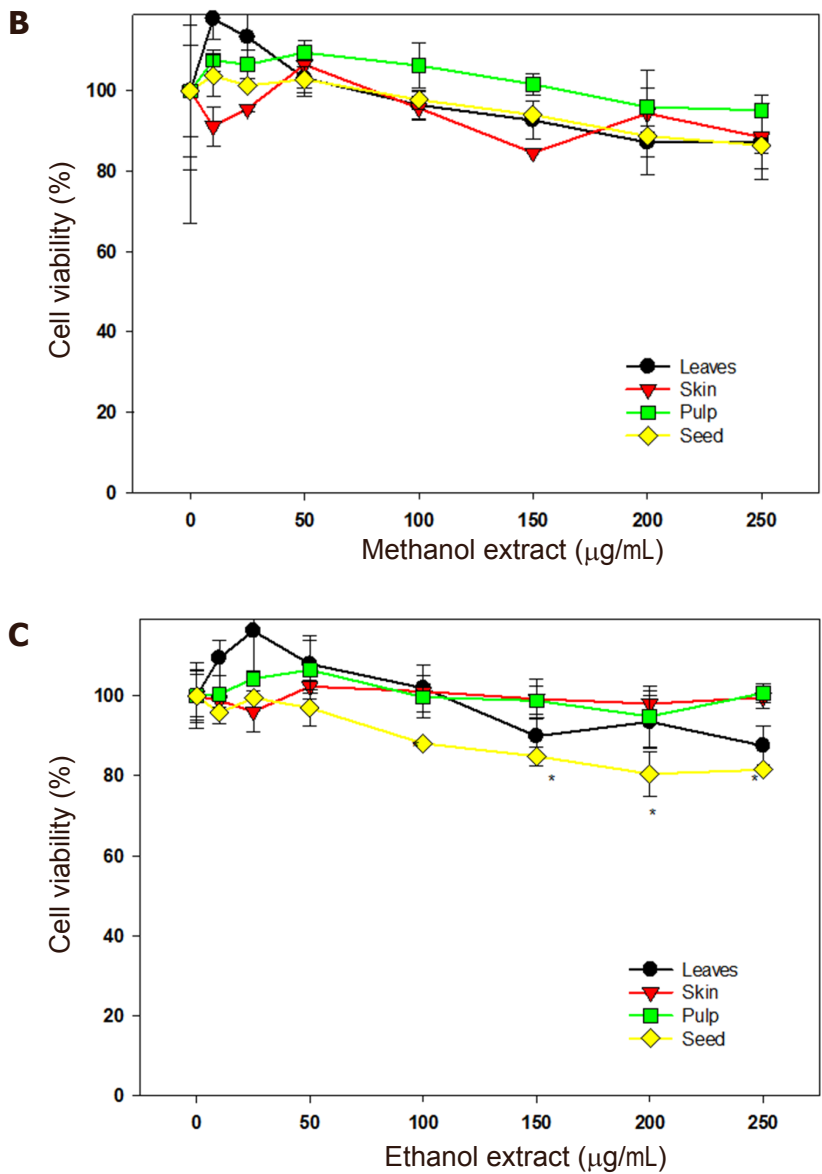

Figure 4. Effect of papaya extracts on MDA-MB-231 breast cancer cells. The effect of water (A), methanol (B), or ethanol (C) extracts on viability of MDA-MB-231 (ER'/Her-2') breast cancer cells was measured as described in the "METHODS". Data is calculated as \% inhibition of cell growth. All significant differences between control and treated cells are indicated by "*" and are reported at $P<0.05$

The effect of methanol extract from leaves and seeds is shown in Figure 6B. The data indicate that none of the papaya fractions has any significant effect on cell viability of SK-Br-3 breast cancer cells.

The effect of ethanol extract from leaves and seeds is shown in Figure 6C. Similar to methanol extracts, the data indicate that none of the ethanol extract from papaya leaves or seeds has any significant effect on cell viability of SK-Br-3 breast cancer cells. 
A

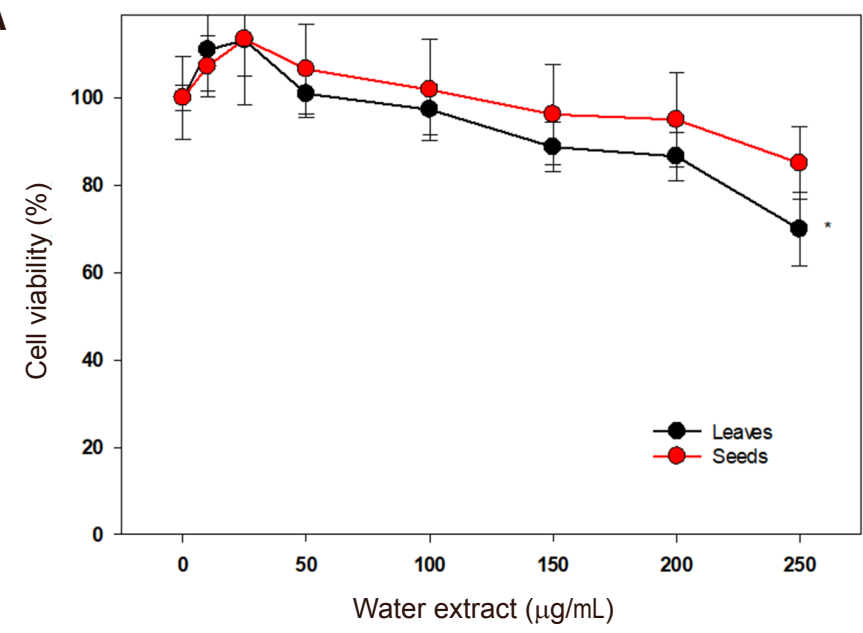

B

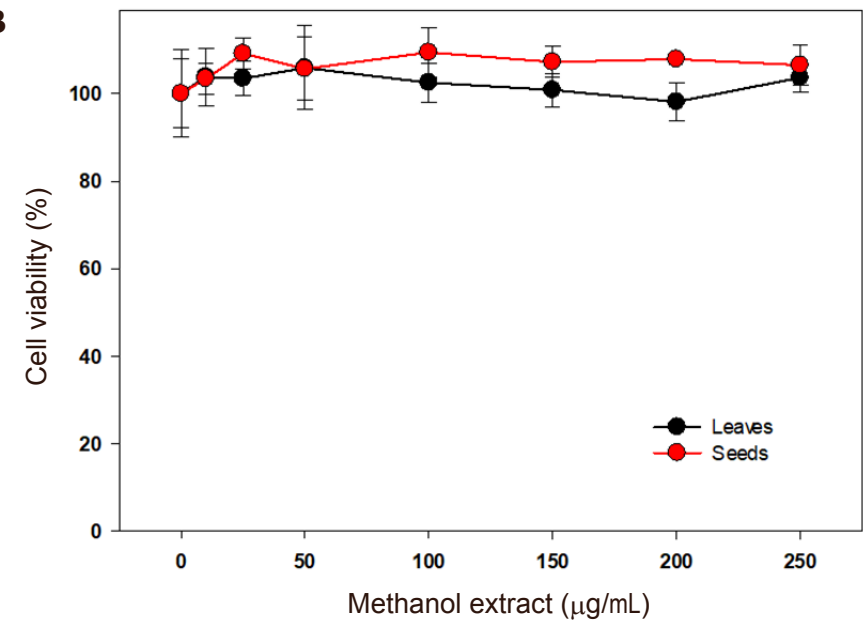

C

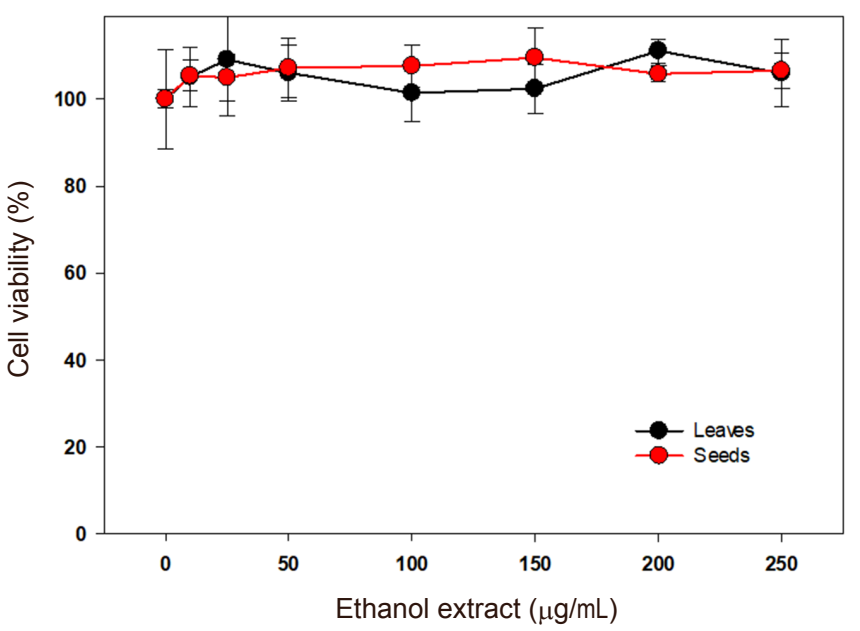

Figure 5. Effect of papaya extracts on MCF-7 breast cancer cells. The effect of water (A), methanol (B), or ethanol (C) extracts on viability of MCF-7 (ER $/$ Her-2) breast cancer cells was measured as described in the "METHODS". All significant differences between control and treated cells are indicated by " $"$ " and are reported at $P<0.05$

\section{Effect of papaya leaves and seeds extract on MDA-MB-361 breast cancer cells}

The effect of papaya extract on $\mathrm{ER}^{+} / \mathrm{Her}-2^{+}$breast cancer cell lines were investigated using MDA-MB-361 cell lines. We again tested only extracts from leaves and seeds as explained earlier. The effect of water extract 
A

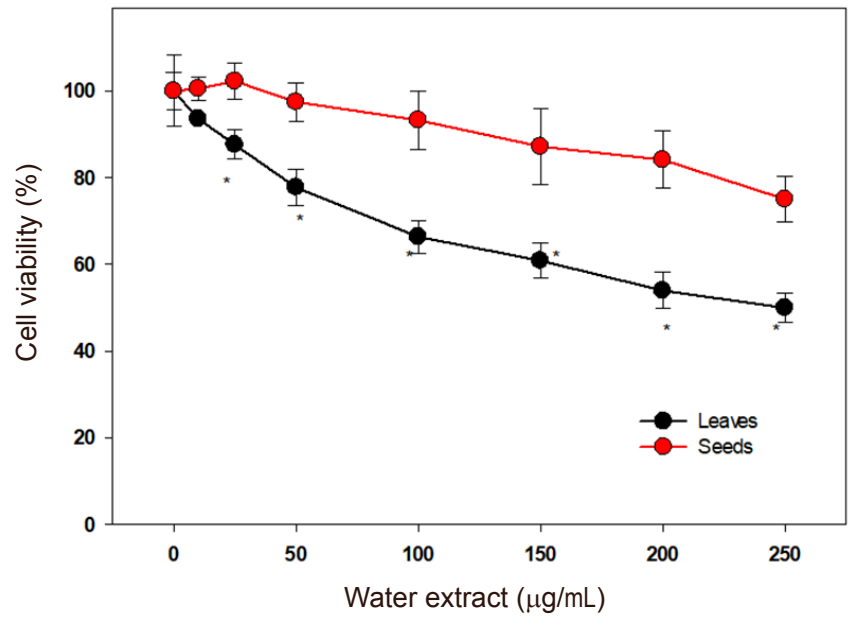

B

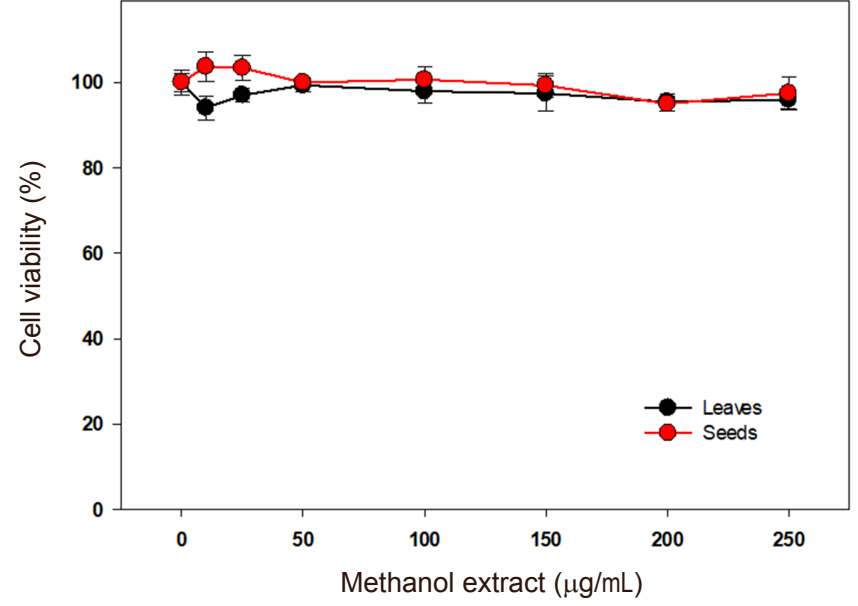

C

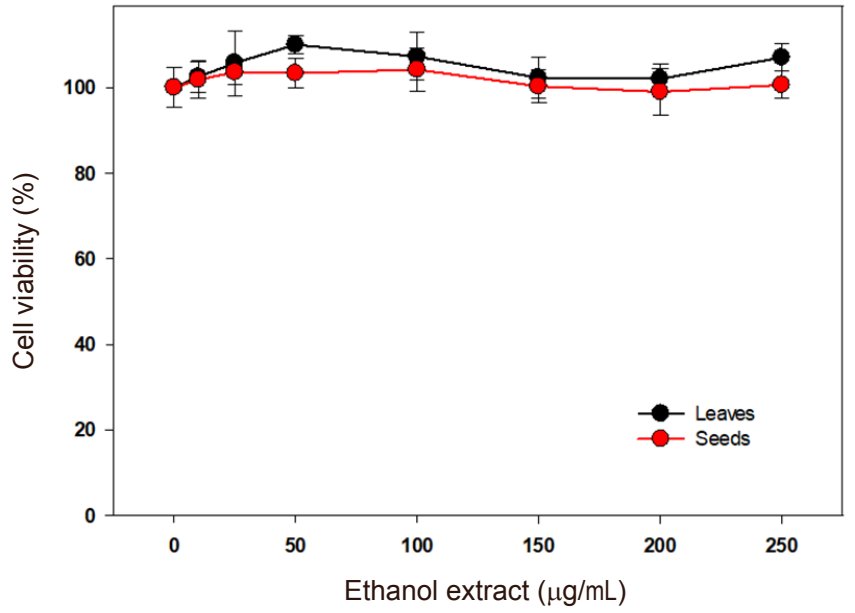

Figure 6. Effect of papaya extracts on SK-Br-3 breast cancer cells. The effect of water (A), methanol (B), or ethanol (C) extracts on viability of SK-Br-3 (ER/Her-2+) breast cancer cells was measured described in the "METHODS". All significant differences between control and treated cells are indicated by " $"$ " and are reported at $P<0.05$

from leaves and seeds is shown in Figure 7A. The extract from seeds and leaves have no significant effect on cell viability of MDA-MB-361 breast cancer cells.

The effect of methanol extract from leaves and seeds is shown in Figure 7B. The data indicate that none of the papaya fractions has any significant effect on cell viability of MDA-MB-361 breast cancer cells. 
A
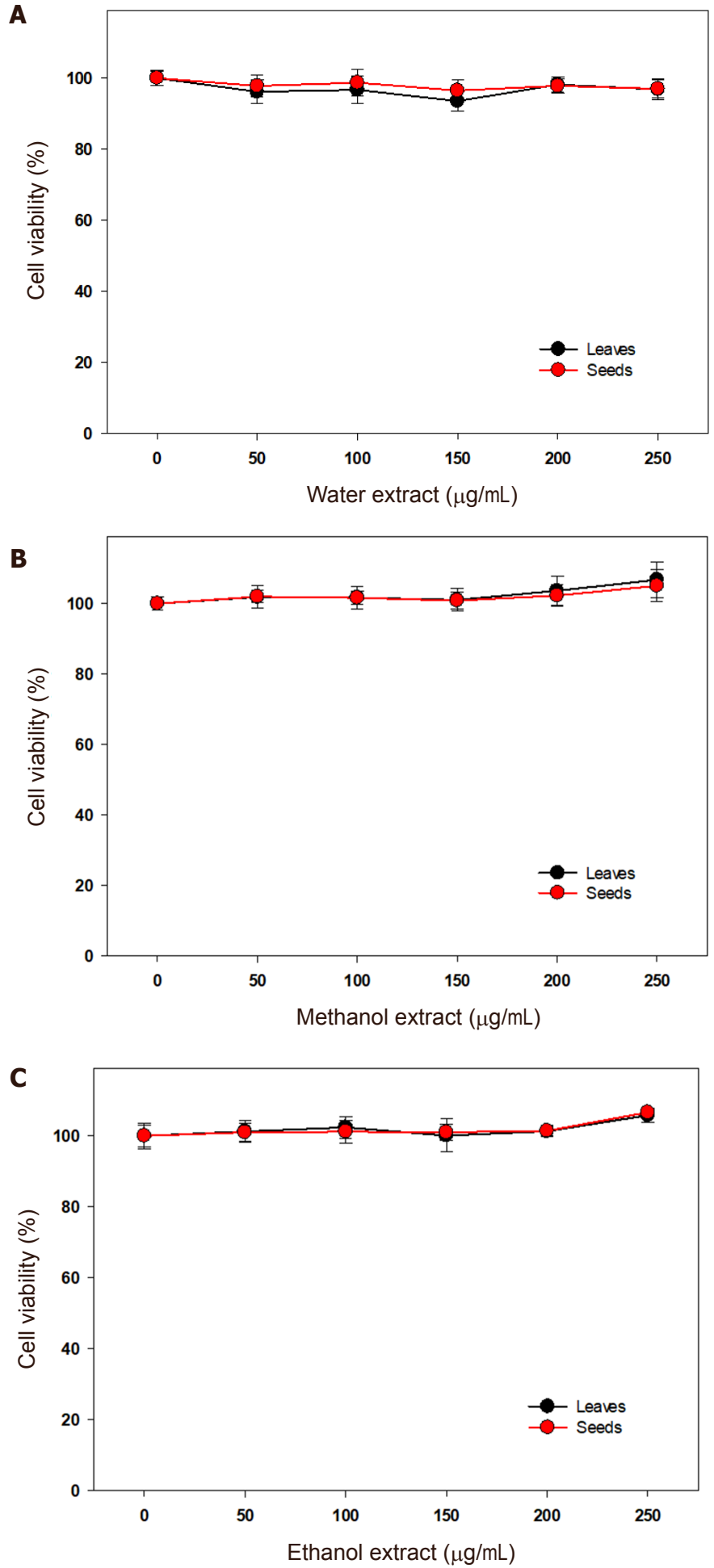

Figure 7. Effect of papaya extracts on MDA-MB-361 breast cancer cells. The effect of water (A), methanol (B), or ethanol (C) extracts on viability of MDA-MB-361 (ER $/$ Her-2 $2^{+}$) breast cancer cells was measured as described in the "METHODS". All significant differences between control and treated cells are indicated by " $"$ " and are reported at $P<0.05$

The effect of ethanol extract from leaves and seeds is shown in Figure $7 \mathrm{C}$. The data indicate that none of the papaya fractions also has any significant effect on cell viability of MDA-MB-361 breast cancer cells.

\section{Effect of papaya leaves and seeds extract on AU565 breast cancer cells}

From data shown above, we found that papaya extract from leaves and seeds were effective against ER cell 
A

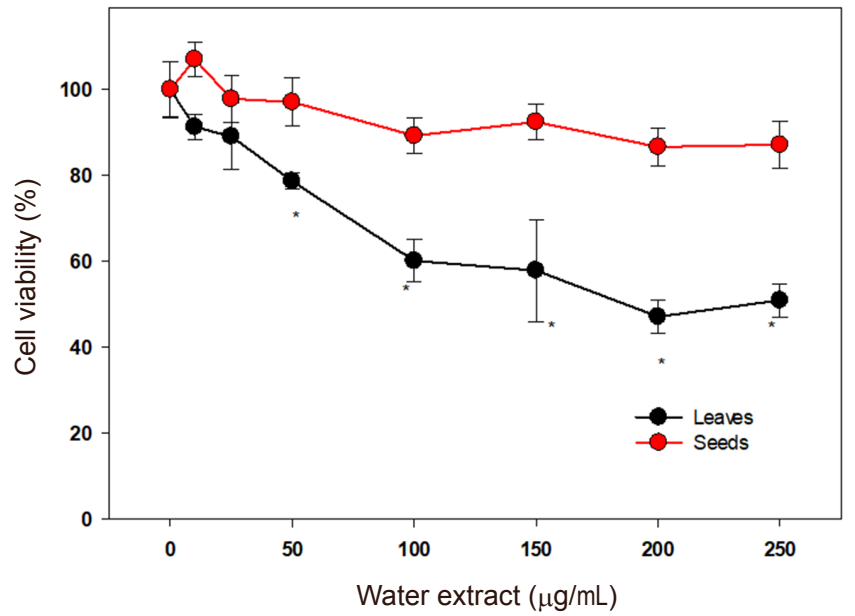

B

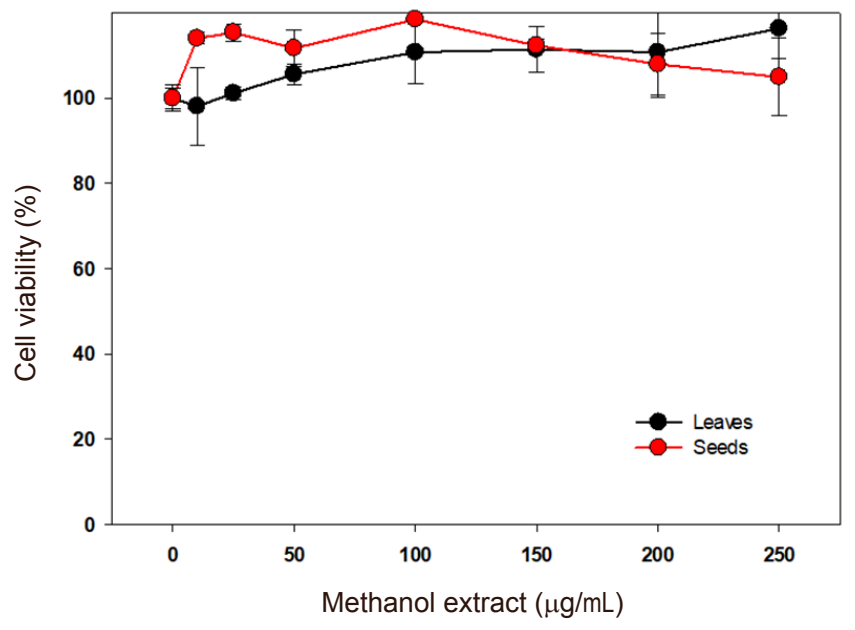

C

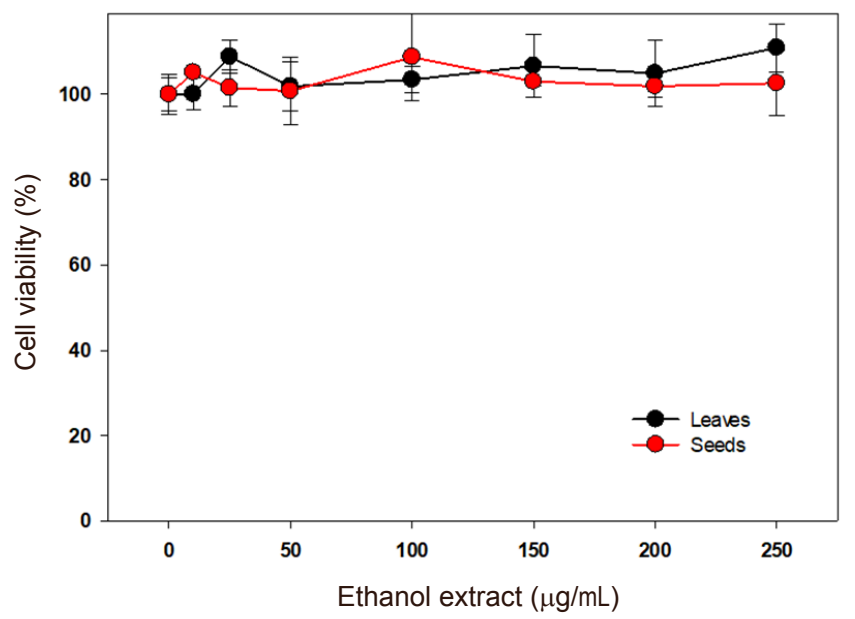

Figure 8. Effect of papaya extracts on AU565 breast cancer cells. The effect of water (A), methanol (B), or ethanol (C) extracts on viability of AU565 $\left(\mathrm{ER}^{-} / \mathrm{Her}-2^{+}\right)$breast cancer cells was measured as described in the "METHODS". All significant differences between control and treated cells are indicated by " $"$ and are reported at $P<0.05$

lines (MDA-MB-231 \& SK-Br-3) irrespective to their Her-2 receptors expression whereas papaya extract from seeds and leaves were not effective on $\mathrm{ER}^{+}$cell lines (MCF-7 \& AU565). To further validate the effects on $\mathrm{ER}^{+}$ breast cancer cells, we used another ER breast cancer cell lines, AU565 cell line (ER//Her-2 $\left.{ }^{+}\right)$.

The effect of water extract from leaves and seeds is shown in Figure 8A. The extract from seeds has no significant effect; however, leaves extract reduced cell viability starting at $50 \mu \mathrm{g} / \mathrm{mL}$. The cell viability 
was reduced significantly by $50 \%(P<0.05)$ at $200-250 \mu \mathrm{g} / \mathrm{mL}$. The effect of methanol extract from leaves and seeds is shown in Figure $8 \mathrm{~B}$. The data indicate that methanol extracts of the papaya leaves and seeds fractions had no significant effect on cell viability of AU565 breast cancer cells. The effect of ethanol extract from leaves and seeds is shown in Figure $8 \mathrm{C}$. The data indicate that ethanol extracts of the papaya leaves and seeds fractions also had no significant effect on cell viability of AU565 breast cancer cells.

\section{DISCUSSION}

The present study was carried out to investigate the effect of water, methanol, and ethanol fractions of papaya's leaf, skin, pulp, and seeds on breast cancer cells. We initially tested these fractions for their antioxidation activity. Most the anti-oxidation activity in fruits and vegetables is due to their total polyphenolic content ${ }^{[40]}$. Our data indicates that seeds have the highest amount of polyphenols than that of other fractions. The leaves also continued substantial amounts of TPC which was $1 / 3$ to that of seeds. Other fractions have very small amounts of TPC. In seeds the amount of TPC was similar in all three extracts but in leaves water extract has less TPC than that methanol or ethanol. Different solvents including water, methanol and ethanol were used during present investigation because the phenolic compounds have different chemical characteristics and polarities and their solubility varies in polar and non-polar solvents ${ }^{[41]}$. Polar solvents are often used for extracting polyphenols from plant samples. Methanol is a very efficient solvent for extracting polyphenols of lower molecular weight, whereas aqueous acetone is generally used for extraction/isolation of higher molecular weight flavanols ${ }^{[42]}$. Ethanol is also a good solvent for polyphenol extraction which is also safe for human consumption. In addition, aqueous mixtures containing methanol, ethanol, ethyl acetate, or acetone have also been used by several investigators. Currently, over 8000 phenolic structures have been identified in fruits and vegetables ${ }^{[43]}$, and flavonoids are one of the major phenolic class comprising of almost 4000 compounds present in different edible plants ${ }^{[43]}$. We also determined the total flavonoids in the papaya extracts. Our data show that water extract of seeds and methanol and ethanol extracts of leaves contained the highest amount of TFC, which represented about 30\%-40\% of total phenolic compounds in seeds and leaves. These data suggest that seeds may contain water soluble small molecular weight polyphenols whereas leaves may contain less water-soluble high molecular weight polyphenols.

Next the anti-oxidation activities were determined in these fractions. The leaves and seeds possess the highest anti-oxidation activities. Although leaves and seeds have different phenolic and flavonoids contents, they have similar profile for their anti-oxidation activity. It was interesting to note that methanol and ethanol extracts exhibited higher anti-oxidation activity than the water extract in all papaya fractions. This difference could be due to the differences in the chemical structure of polyphenols and perhaps polyphenols are more soluble in an aqueous mixture of methanol or ethanol than water alone.

The different extracts from various fractions of papaya were used to determine their effects in breast cancer cells. As explained in the introduction section, breast cancer is characterized by different molecular phenotypes. In our initial studies, not much anti-cancer activity was found in pulp and skin extracts. These fractions were also very low in their polyphenolic contents. On the other hand, leaves and seeds showed anti-cancer activity and these fractions have significant amounts of polyphenols. The subsequent experiments were, therefore, performed only using leaves and seeds extracts. MDA-MB-231 was a representative of ER/Her-2 breast cancer subtype. The water extracts of leaves and seeds were effective on these cells. The methanol and ethanol extract showed no significant effect. MCF-7 cells line was used as a representative of $\mathrm{ER}^{+} / \mathrm{Her}-2$ breast cancer. None of the extracts from seeds or leaves exhibited any effect on these cell lines. Sk-Br-3 cells were used as a representative of ER/Her-2 ${ }^{+}$breast cancer subtype. It is clear from the data that only water extract of leaves exhibited effect on these cells line. MDA-MB-361 cell line was used as a representative of $\mathrm{ER}^{+} / \mathrm{Her}_{-}{ }^{+}$breast cancer subtype. Again, no effect was found by any of the leaves or seeds extract on these cell lines. From this data it is clear that only ER breast cancer cells irrespective to their Her-2 expression were significantly affected by water extracts of leaves. Whereas $\mathrm{ER}^{+}$ 
cells were largely unaffected. To further validate this finding, AU565, another ER breast cancer cell line, was used. Similar to Sk-Br-3, water extract of papaya leaves also inhibited growth of this cell lines. These data, therefore, confirm the effect of water extracts from leaves on ER subtypes of breast cancer, which are difficult to treat. This observation indicates that water-soluble, small molecular weight compounds present in papaya leaves may be responsible for the anticancer activity in ER breast cancer cell lines.

It is also interesting to note that both seeds and leaves extracts were similar in their anti-oxidation activity; however, leaf extracts inhibited ER breast cancer cell growth more potently than that of seeds extracts. It is clear from this observation that the antioxidation activity may not have attributed to their anticancer activity. Our results are consistent to other studies where growth inhibition of MCF-7 cells by pomegranate extract was not attributed to its high antioxidant potential ${ }^{[44]}$. It appears that the inhibitory compounds in the water extract of papaya leaves acted on cellular mechanism that are involved in regulating cell growth. During the present investigation, the phenolic composition of water extracts of leaves was not determined. However, it has been shown that papaya leaves extract contained proanthocyanidins and saponins classes of phenolic compounds. Water extract of papaya is commonly consumed to prevent/treat other diseases in traditional medicine ${ }^{[45]}$. This observation suggests that consumption of papaya leaf extract is probably safe. Furthermore, our data are consistent with previous studies, suggesting that papaya leaves can be beneficial for a number of cancers including breast cancer $^{[35]}$.

Our data is interesting because ER or triple negative tumors have limited options for the treatment. Triplenegative breast cancers do not have estrogen, progesterone, or Her-2 receptors and treatment with drugs designed to interfere hormone activities is not effective in these receptor-negative cancer cells. These cancers often grow faster than receptor-positive breast cancers. In most cases pre-menopausal women develop hormone receptor-negative cancers and appears to be common in younger women and in women with African-American or Hispanic/Latina ancestry ${ }^{[46]}$. Some of the ER breast cancers are Her-2 positive that cancer are now effectively targeted with Herceptin, which is an antibody for Her-2 proteins ${ }^{[47]}$. The ER/Her-2 breast cancers do not benefit from anti-estrogen and/or anti-Her-2 based therapy. The options for treating such cancer are limited and involved surgery or chemotherapy, or both ${ }^{[48]}$. The drugs that are used to target such tumors are based on inhibition of cell proliferation pathways. Drugs including taxanes, anthracyclin, acts on DNA repair complex like, anti-oncogene P53, and stabilizing microtubules ${ }^{[49]}$. The effect of papaya leaves water extracts on ER breast cancer cells in our study appears to be at a moderate level. However, the extract can be concentrated for more aggressive effects. In addition, papaya leaves extracts can be used as an adjunct therapy with the generally prescribed anti-cancer drugs, which may improve the efficacy of the drugs and also reduce the side effects and drug resistance in breast cancer patients. Furthermore, our in vitro data needs to be validated in an in vivo animal model.

In conclusion, water extract of papaya leaves containing water soluble polyphenols may have a potential to inhibit ER breast cancer. However, further studies are required to determine the actual chemical nature of these phenolic compounds and their mechanism of action.

\section{DECLARATIONS}

\section{Authors' contributions}

Concept and design: Siddiqui RA, Rafei R

Manuscript preparation, editing, and review: Siddiqui RA, Kaseloo P, Witiak SM

Experimental studies, data acquisition, data analysis, statistical analysis: Li H, Hadadi SA

\section{Data source and availability}

Data were obtained in Food Chemistry and Nutrition Science Laboratory, Agricultural Research Station, Virginia State University, Petersburg, VA 23806. The data are available in electronic format as Excel and Sigma plot files upon request. 


\section{Financial support and sponsorship}

The work was supported by funds from Evans-Allen Research program FY2017, USDA, Agricultural Research Station, Virginia State University, Petersburg, Virginia. The financial support to Shrefa Hadadi was provided by Saudi Arabian Culture Mission, Kingdom of Saudi Arabia.

\section{Conflicts of interest}

There are no conflicts of interest.

\section{Patient consent}

Not applicable.

\section{Ethics approval}

Animal or human tissues were not used; no ethical approval was required.

\section{Copyright}

(c) The Author(s) 2018.

\section{REFERENCES}

1. American Cancer Society. Cancer is the second most common cause of death in the United States, exceeded only by heart disease. In: Cancer Facts \& Figures 2006. Atlanta, GA: American Cancer Society; 2006.

2. Siegel RL, Miller KD, Jemal A. Cancer Statistics, 2017. CA Cancer J Clin 2017;67:7-30.

3. Ferlay J, Soerjomataram I, Ervik M, Dikshit R, Eser S, Mathers C, Rebelo M, Parkin DM, Forman D, Bray F. Cancer incidence and mortality worldwide: sources, methods and major patterns in GLOBOCAN 2012. Int J Cancer 2015;136:E359-86.

4. Davidson NE, Armstrong SA, Coussens LM, Cruz-Correa MR, DeBerardinis RJ, Doroshow JH, Foti M, Hwu P, Kensler TW, Morrow M, Mulligan CG, Pao W, Platz EA, Smith TJ, Willman CL. AACR Cancer Progress Report 2016. Clin Cancer Res 2016;22:S1-137.

5. Onitilo AA, Engel JM, Greenlee RT, Mukesh BN. Breast cancer subtypes based on ER/PR and Her2 expression: comparison of clinicopathologic features and survival. Clin Med Res 2009;7:4-13.

6. Wagner AD, Thomssen C, Haertin J, Unverzagt S. Vascular-endothelial-growth-factor (VEGF) targeting therapies for endocrine refractory or resistant metastatic breast cancer. Cochrane Database Syst Rev 2012;1:CD008941.

7. Jordan VC. Tamoxifen treatment for breast cancer: concept to gold standard. Oncology (Williston Park) 1997;11:7-13.

8. Ahmed S, James K, Owen CP, Patel CK, Patel M. Novel inhibitors of the enzyme estrone sulfatase (ES). Bioorg Med Chem Lett 2001;11:841-4.

9. Altundag K, Ibrahim NK. Aromatase inhibitors in breast cancer: an overview. Oncologist 2006;11:553-62.

10. Garrett JT, Rawale S, Allen SD, Phillips G, Forni G, Morris JC, Kaumaya PT. Novel engineered trastuzumab conformational epitopes demonstrate in vitro and in vivo antitumour properties against HER-2/neu. J Immunol 2007;178:7120-31.

11. Lurje G, Lenz HJ. EGFR signaling and drug discovery. Oncology 2009;77:400-10.

12. Valabrega G, Montemurro F, Aglietta M. Trastuzumab: mechanism of action, resistance and future perspectives in HER2-overexpressing breast cancer. Ann Oncol 2007;18:977-84.

13. Dean-Colomb W, Esteva FJ. HER2-positive breast cancer: herceptin and beyond. Eur J Cancer 2008;44:2806-12.

14. Jain RK, Carmeliet PF. Vessels of death or life. Sci Am 2001;285:38-45.

15. Shih T, Lindley C. Bevacizumab: an angiogenesis inhibitor for the treatment of solid malignancies. Clin Ther 2006;28:1779-802.

16. Gotink KJ, Verheul HM. Anti-angiogenic tyrosine kinase inhibitors: what is their mechanism of action? Angiogenesis 2010;13:1-14.

17. Farvid MS, Cho E, Chen WY, Eliassen AH, Willett WC. Dietary protein sources in early adulthood and breast cancer incidence: prospective cohort study. BMJ 2014;348:g3437.

18. Kim MK, Kim JH, Nam SJ, Ryu S, Kong G. Dietary intake of soy protein and tofu in association with breast cancer risk based on a casecontrol study. Nutr Cancer 2008;60:568-76.

19. Nechuta SJ, Caan BJ, Chen WY, Lu W, Chen Z, Kwan ML, Flatt SW, Zheng Y, Zheng W, Pierce JP. Soy food intake after diagnosis of breast cancer and survival: an in-depth analysis of combined evidence from cohort studies of US and Chinese women. Am J Clin Nutr 2012;96:123-32.

20. Thomson CA, Rock CL, Thompson PA, Caan BJ, Cussler E, Flatt SW, Pierce JP. Vegetable intake is associated with reduced breast cancer recurrence in tamoxifen users: a secondary analysis from the Women's Healthy Eating and Living Study. Breast Cancer Res Treat 2011;125:519-27.

21. Lv ZD, Liu XP, Zhao WJ, Dong Q, Li FN, Wang HB, Kong B. Curcumin induces apoptosis in breast cancer cells and inhibits tumor growth in vitro and in vivo. Int J Clin Exp Pathol 2014;7:2818-24.

22. Hu XJ, Xie MY, Kluxen FM, Diel P. Genistein modulates the anti-tumoractivity of cisplatin in MCF-7 breast and HT-29 colon cancer cells. Arch Toxicol 2014;88:625-35.

23. Cai Q, Shu XO, Wen W, Cheng JR, Dai Q, Gao YT, Zheng W. Genetic polymorphism in the manganese superoxide dismutase gene, 
antioxidant intake, and breast cancer risk: results from the Shanghai Breast Cancer Study. Breast Cancer Res 2004;6:R647-55.

24. Roy D, Liehr JG. Estrogen, DNA damage and mutation. Mutat Res 1999;424:107-15.

25. Galati G, O’Brien PJ. Potential toxicity of flavonoids and other dietary phenolics: significance for their chemopreventive and anticancer properties. Free Radic Biol Med 2004;37:287-303.

26. Bonofiglio D, Giordano C, de Amicis F, Lanzino M, Ando S. Natural products aspromising antitumoral agents in breast cancer: mechanisms of action and moleculartargets. Mini Rev Med Chem 2016;16:596-604.

27. Krishna KL, Paridhavi M, Patel JA. Review on nutritional, medicinal and pharmacological properties of papaya (Carica papaya Linn.). Nat Prod Rad 2008;7:364-73.

28. Lohsoonthorn P, Danvivat D. Colorectal cancer risk factors: a case-control study in Bangkok. Asia Pac J Public Health 1995;8:118-22.

29. Shahar S, Shafurah S, Shaari H, Rajikan R, Rajab NF, Golkhalkhali B, Zainuddin ZM. Roles of diet, lifetime physical activity and oxidative DNA damage in the occurrence of prostate cancer among men in Klang Valley, Malaysia. Asian Pac J Cancer Prev 2011;12:605-11.

30. Pandey S, Walpole C, Cabot PJ, Shaw PN, Batra J, Hewavitharana AK. Selective anti-proliferative activities of Carica papaya leaf juice extracts against prostate cancer. Biomed Pharmacother 2017;89:515-23.

31. Siegel EM, Salemi JL, Villa LL, Ferenczy A, Franco EL, Giuliano AR. Dietary consumption of antioxidant nutrients and risk of incident cervical intraepithelial neoplasia. Gynecol Oncol 2010;18:289-94.

32. Zhang CX, Ho SC, Chen YM, Fu JH, Cheng SZ, Lin FY. Greater vegetable and fruit intake is associated with a lower risk of breast cancer among Chinese women. Int J Cancer 2009;125:181-8.

33. Nakamura Y, Yoshimoto M, Murata Y, Shimoishi Y, Asai Y, Park EY, Sato K, Nakamura Y. Papaya seed represents a rich source of biologically active isothiocyanate. J Agric Food Chem 2007;55:4407-13.

34. Garcia-Solis P, Yahia EM, Morales-Tlalpan V, Diaz-Munoz M. Screening of antiproliferative effect of aqueous extracts of plant foods consumed in Mexico on the breast cancer cell line MCF-7. Int J Food Sci Nutr 2009;60:32-46.

35. Otsuki N, Dang NH, Kumagai E, Kondo A, Iwata S, Morimoto C. Aqueous extract of Carica papaya leaves exhibits anti-tumor activity and immunomodulatory effects. J Ethnopharmacol 2010;127:760-7.

36. Sancho L, Yahia E, García-Solís P, González-Aguilar G. Inhibition of proliferation of breast cancer cells MCF7 and MDA-MB-231 by lipophilic extracts of papaya (Carica papaya L. var. Maradol) fruit. Food Nutr Sci 2014;5:2097-103.

37. Kaur C, Kapoor HC. Anti-oxidant activity and total phenolic content of some Asian vegetables. Int J Food Sci Technol 2002;37:153-61.

38. Chang C, Yang M, Wen H, Chern J. Estimation of total flavonoid content inpropolis by two complementary colorimetric methods. J Food Drug Anal 2002;10:178-82.

39. Villano D, Fernandez-Pachon MS, Moya ML. Troncoso AM, Garcia-Parrilla MC. Radical scavenging ability of polyphenolic compounds towards DPPH free radical. Talanta 2007;71:230-5.

40. Álvarez R, Araya H, Navarro-Lisboa R, Lopez de Dicastillo C. Evaluation of polyphenol content and antioxidant capacity of fruits and vegetables using a modified enzymatic extraction. Food Technol Biotechnol 2016;54:462-7.

41. Turkmen N, Sari F, Velioglu YS. Effects of extraction solvents on concentration and antioxidant activity of black and black mate tea polyphenols determined by ferroustartrate and Foline-Ciocalteu methods. Food Chem 2006;99:835-41.

42. Dai J, Mumper RJ. Plant phenolics: extraction, analysis and their antioxidant andanticancer properties. Molecules 2010;15:7313-52.

43. Tsao R. Chemistry and biochemistry of dietary polyphenols. Nutrients 2010;2:1231-46.

44. Shirode AB, Kovvuru P, Chittur SV, Henning SM, Heber D, Reliene R. Antiproliferative effects of pomegranate extract in MCF-7 breast cancer cells are associated with reduced DNA repair gene expression and induction of double strand breaks. Mol Carcinog 2004;53:458-70.

45. Nguyen TT, Parat MO, Shaw PN, Hewavitharana AK, Hodson MP. Traditional aboriginal preparation alters the chemical profile of carica papaya leaves and impacts on cytotoxicity towards human squamous cell carcinoma. PLoS One 2016;1: e0147956.

46. Aravind G, Bhowmik D, Duraivel S, Harish G. Traditional and medicinal uses of carica papaya. J Med Plants Stud 2013;1:7-15.

47. Aruljothi S, Uma C, Sivagurunathan P, Bhuvaneswari M. Investigation on antibacterial activity of carica papaya leaf extracts against wound infection-causing bacterial. Int J Res Stud Biosci 2004;11:8-12.

48. Trock BJ. Breast cancer in African American women: epidemiology and tumor biology. Breast Cancer Res Treat 1996;40:11-24.

49. Edwardson D, Chewchuk S, Parissenti AM. Resistance to Anthracyclines and Taxanes in Breast Cancer. In: Ahmad A, editor. Breast Cancer Metastasis and Drug Resistance. New York, NY: Springer; 2013. p. 227-47. 